\title{
Board of Commisioner Duality Role, Governance and Earnings Management of Initial Public Offerings in Indonesia
}

\author{
Tatang Ary Gumanti ${ }^{1}$ and Widi Prasetiawati ${ }^{2}$ \\ 1) Fakultas Ekonomi Jurusan Manajemen dan Akuntansi, Universitas Jember \\ Email: tatangag@unej.ac.id \\ 2) Komisi Pemilihan Umum Nganjuk
}

\begin{abstract}
Public firm is required to implement good corporate governance as assurance to reduce information asymmetry between firm and its stockholders. Corporate governance mechanism should be able to limit any improper actions of the firm's management. This study investigates whether the duality role of the board affects earnings management practice of firms making initial public offering at Indonesian Stock Exchange. The study also examines other corporate governance mechanism factors, namely the number of board of commissionners, the proportion of independent board of commissioners, size of firm, financial leverage, and profitability. Earnings management was measured using Cross-Sectional Modified Jones model. The study employs a total of 60 firms that went public from 2000 to 2006 . The results show that duality status of board of commissioners positively and significantly affects earnings management in IPO firms. This could be interpreted that board of directors with duality role had a lower function in monitoring the firms' performance so that management have opportunity to manage reported earnings. When board of commissioners have dual role, the level of earnings management is getting intense, and vice versa. Size of board of commissioners and profitability are positively related to earnings management.
\end{abstract}

Keywords: Board of directors, duality status, earnings management, IPO.

\section{INTRODUCTION}

When making Initial Public Offering (IPO), a firm will issue prospectus which largely contains information related to financial data. Yet, in IPO setting, manager has strong motivation to opportunistically alter reported earnings, namely earnings management, in an effort to obtain investors' positive valuation (Healy, 2000). Earnings management is not uncommon in an IPO setting (Friedlan, 1994; Teoh et al, 1998).

Following financial scandals in the US in late 1990, stock exchange authorities imposed firms to performed Good Corporate Governance (GCG), including firm wishing to go public. Guest (2008) suggests one of potential aspect in GCG mechanism is the presence of Board of Commissioners (BoC). A well structure BoC is expected to reduce manager opportunistic behavior in performing earnings management. $\mathrm{BoC}$ characteristic, in particular its composition, should effectively have contributed to the production of qualified financial reports that will hinder or reduce possibility of financial misrepresentation.

Aharony et al. (1993) did not find a strong evidence of earnings management in the US IPOs, but others, such as Friedlan (1994), Neill et al.
(1995), Magnan and Cournier (1997) or Teoh et al. (1998) did. Tykova (2006) find the evidence in Germany. In Indonesia, Gumanti (2001) examines IPO firms between 1995 and 1997 and finds no evidence of earnings management a year prior to the IPO, but shows strong evidence in period two years prior to IPO. Saiful (2004) and Joni (2008) report strong evidence of earnings management in Indonesian IPOs.

Studies have found negative relationship between $\mathrm{BoC}$ and earnings management. Saleh et al. (2005) and Rahman and Ali (2006) document the evidence in Malaysian public firms, whilst Peasnell et al. (2005) in UK, and Klein (2002) in the US. In Indonesia, Guna and Herawati (2010) do not find that the presence of independent BoC affect earnings management.

Study examining the presence of dual role of $\mathrm{BoC}$ and Board of Director (BoD) in reducing the level of earnings management in an IPO setting is limited. One of it is Saleh et al (2005) who find that duality role of $\mathrm{BoD}$ positively affect earnings management.

Motivated by previous finding and limited evidence on the issue of corporate governance and IPO, this study examines the effect of duality role of $\mathrm{BoC}$ on earnings management in Indonesian IPO firms during 2000-2006. 
Earnings management is a widespread phenomenon. It is found in various setting, including in an IPO. The issuers' intention of gaining larger proceeds from IPO has led to opportunistic behavior by inflating reported income. Friedlan (1994), Teoh et al. (1998), and Tykova 2006, among others, document evidence of earnings management sin the periods prior to IPO date. In Indonesia, Gumanti (2001) and Amin (2007) find such evidence.

BoCs monitor the firm (i.e., the Directors) to ascertain that the firm is managed properly. $\mathrm{BoC}$ has exclusive independency aside of $\mathrm{BoD}$. According to stewardship theory, to improve firm performance there seems to be a need of the duality role of the $\mathrm{BoC}$ and $\mathrm{BoD}$ of which $\mathrm{BoC}$ may have intervention to $\mathrm{BoD}$ in ascertaining the achievement of firm's goals (Rechner dan Dalton, 1991). Saleh et al. (2005) show that firm with duality role of $\mathrm{BoC}$ and $\mathrm{BoD}$ have positive effect on earnings management. Whilst, Klein (2002) shows that directors having more power over the $\mathrm{BoC}$ have higher motivation to manage reported earnings. It seems that duality role has positive effect on earnings management. This leads to the following hypothesis:

$\mathrm{H}_{1}$ : Duality role of Board of Commissioner increases the level of earnings management of IPO firms

The effect of $\mathrm{BoC}$ size on earnings management is mixed though it has significant effect on firm performance (Pierce and Zahra, 1992). Rahman and Ali (2006) show larger size of BoC does not lead to effective monitoring and solve problem of the firm in Malaysia. Yermack (1996) finds negative effect of size of $\mathrm{BoC}$ on CEO's misconduct. Beasley (1996) conclude that lower BoC size leads to more effective monitoring. Larger $\mathrm{BoC}$ is seemed to be less effective in playing their roles as there are communication problems, coordination, and decision making. Conversely, Dalton et al. (1999) and Bradbury et al. (2006) contend larger $\mathrm{BoC}$ size will provide better business management that will limit the level of earnings management. Based on this contention, the following hypothesis is proposed:

$\mathrm{H}_{2}$ : Larger size of Board of Commissioner reduces the level earnings management of IPO firms

BoC effectiveness as balancing power of CEO is heavily affected by their independency. Agency theory supports the view that to improve BoC independency, the board shall be dominated by outside directors. The presence of outside directors is needed to monitor and control directors' actions (Jensen and Meckling, 1976). Non executive direc- tors will affect decision making to improve firms' performance (Zahra dan Pearce, 1998). Thus, management is forced to take responsibility and consider the interest of shareholders or stakeholders.

Fama and Jensen (1983) state that independent commissioner could help overcoming potential conflict between managers and control and provide consideration to management of the firm. Independent commissioner is in good position for monitoring process so to ascertain that good corporate government is in place, which in turn could reduce the use of discretionary accruals (Cornett et al., 2006). This leads to the following hypothesis:

$\mathrm{H}_{3}$ : The presence of independent Board of Commissioner reduces the level of earnings management of IPO firms

Firm size is examined in line with political cost hypothesis' view that large firms tend to lower profit potential by managing accruals. The study predicts that firm size will have negative effect on earnings management of IPOs. Debt covenant hypothesis predicts that firms with large leverage will have greater incentive to increase reported earnings through income increasing discretionary accruals (Godfrey and Koh, 2003. Thus it is predicted that firms' leverage will have positive relation with earnings management of IPOs.

Dechow et al. (1995) and Kaznik (1999) assert that profitability is positively related to discretionary accruals. In an IPO context, profitability seems to be one of key aspects where investors rely the value of the firm from its ability to generate profits. This will motivate issuers to pay more attention on profitability (Healy and Wahlen, 1999). Teoh et al. (1998) provide support of this prediction. Thus, it is predicted that profitability is positively related to earnings management of IPOs.

\section{RESEARCH METHODS}

Indonesia IPO firms that went public in Indonesia stock exchange from 2000 to 2006 were the target of this study. A total 112 IPO firms were identified. Firm is excluded if its prospectus contain less than three years of financial reports. Further, financial, insurance, and real estate firms were excluded. The firm shall have at least four firms members in the same sub-sector as the study employs sub-sector industry in estimating discretionary current accruals.

A modified Jones model (1991) adjusting for industry sector was employed to measure discretionnary accruals (Bradbury et al, 2006; Rahman and Ali, 2006; Tykova, 2006), as performing a time series model is impossible given limited number of 
observation. This means the study estimates current accrual and non-discretionary current accruals based on each sub-sector (firm $\mathrm{j}$ ) in year $t$ using all financial report of the firm in the same sub-sector except the issuing firm. The procedures are as follows:

a. Nondiscretionary accruals is derived using the following formula:

$$
\frac{C A_{j k, t}}{T A_{j k, t-1}}=\alpha_{j, t, 0} \frac{1}{T A_{j k, t-1}}+\alpha_{j, t, 1} \frac{\Delta R E V_{j k, t}}{T A_{j k, t-1}}+\varepsilon_{j k, t}
$$

b. NDCAs are measured using the following equation:

$$
N D C A_{j i, t}=\alpha_{j, t, 0} \frac{1}{T A_{j i, t-1}}+\alpha_{j, t, 1} \frac{\Delta R E V_{j i, t}-\Delta T R_{j i, t}}{T A_{j i, t-1}}
$$

c. DCAs are obtained using the following equation:

$$
D C A_{j i, t}=\frac{C A_{j i, t}}{T A_{j i, t-1}}-N D C A_{j i, t}
$$

where $C A_{j k, t}$ is current accruals, $T A_{j k, t-1}$ is total assets, $\triangle R E V_{j k, t}$ is difference of sales, $N D C A_{j i, t}$ is nondiscretionary accruals component, $T A_{j i, t-1}$ is total asset, $\triangle R E V_{j i, t}$ isdifference of income of IPO, $\Delta T R_{j i, t}$ is difference in account receivable, $D C A_{j i, t}$ is discretionary current accruals, $C A_{j k, t}$ is current accruals, and $\mathrm{j}, \mathrm{k}, \mathrm{t}$ indicate sub-sector $\mathrm{j}$, firm $\mathrm{k}$, and the period, respectively.

Duality role of BoC (DUAL) is dummy variable, the score would be one if the firm has $\mathrm{BoC}$ with dual roles, otherwise zero (Saleh et al., 2005). Size of $\mathrm{BoC}$ is measured as the number of $\mathrm{BoC}$ (Beiner et al., 2004). The presence of independent $\mathrm{BoC}$ is a dummy variable, firm with independent $\mathrm{BoC}$ would be labeled 1, otherwise 0. Firm size is measured using LnTotal Assets (Bradbury et al., 2006). Leverage is measured as the ratio of long term liabilities over total assets. Profitability is measured as the ratio of operating profit before tax over total asset at the end of final year prior to IPO (Saleh et al., 2005). The following regression model is employed.

$\mathrm{DCA}=\mathrm{b}_{0}+\mathrm{b}_{1} \mathrm{DUAL}+\mathrm{b}_{2} \mathrm{SC}+\mathrm{b}_{3} \mathrm{IND}+\mathrm{b}_{4} \mathrm{FS}+$ $b_{5} \mathrm{LEV}+\mathrm{b}_{6} \mathrm{PRO}+\mathrm{e}$

where DCA is discretionary current accruals, DUAL is duality role of BoC, SC is size of BoC, IND is independent BoC, FS is firm size, LEV is Leverage, and Pro is profitability.

\section{RESULTS AND DISCUSSIONS}

Table 1 shows the sample firms selection process. A total of 60 IPOs from 112 IPOs during 2000-2006 meet the selection criteria excluding IPOs in financial, real estate and property industry, IPOs with insufficient member of sub-sector,

\begin{tabular}{|c|c|c|}
\hline No. & Description & Number of firms \\
\hline 1. & $\begin{array}{l}\text { Firms making IPO (year 2000- } \\
\text { 2006) }\end{array}$ & 112 \\
\hline 2. & $\begin{array}{l}\text { Firms in finance, insurance, and } \\
\text { real estate industry }\end{array}$ & 41 \\
\hline 3. & $\begin{array}{l}\text { Firms having less than three } \\
\text { years financial reports. }\end{array}$ & 3 \\
\hline 4. & $\begin{array}{l}\text { Firms with less than three } \\
\text { firms member in the same sub- } \\
\text { sector }\end{array}$ & 3 \\
\hline 5. & $\begin{array}{l}\text { Firms with extreme DCS and } \\
\text { negative equity }\end{array}$ & $5-$ \\
\hline 6. & Final Sample & 60 \\
\hline
\end{tabular}
and IPOs with extreme DAC values.
Table 1. Sample Determination Process

Table 2. Descriptive Statistics of Variables $(n=60)$

\begin{tabular}{lccccccc}
\hline $\begin{array}{l}\text { Descrip- } \\
\text { tion }\end{array}$ & DCA & DUAL & SC & IND & FS & LEV & PRO \\
\hline Mean & -0.3559 & 0.7667 & 3.4000 & 0.3500 & 11.0957 & 0.1787 & 0.0751 \\
Standard & 0.2302 & 0.0551 & 0.1750 & 0.0621 & 0.1003 & 0.0273 & 0.0188 \\
Error & & & & & & & \\
Median & -0.0450 & 1.0000 & 3.0000 & 0.0000 & 10.9889 & 0.1136 & 0.0505 \\
$\begin{array}{l}\text { Standard } \\
\text { Deviation }\end{array}$ & 1.7833 & 0.4265 & 1.3555 & 0.4810 & 0.7769 & 0.2115 & 0.1453 \\
Minimum & -7.5186 & 0.0000 & 2.0000 & 0.0000 & 9.2480 & 0.0000 & -0.2391 \\
Maximum & 6.3706 & 1.0000 & 10.0000 & 1.0000 & 12.8112 & 0.8335 & 0.6147
\end{tabular}

Notes:

DCA = discretionary current accruals, DUAL = duality role of BoC, SC = Size of BoC, IND = Independent BoC, $\mathrm{FS}=$ firm size, $\mathrm{LEV}=$ leverage, $\mathrm{PRO}=$ Profitability.

Table 2 shows descriptive statistics of variables. There are 46 firms with dual role, i.e., being a commissioner and director and 21 firms have independent $\mathrm{BoC}$ at IPO date. Average DCA is negative indicating IPOs tend to make income decreasing discretionary accruals in the period before the IPO, where a total of 35 firms have negative DCA. This is in contrast to Hastoro and Yuliana (2010) who found positive and significant discretionary accruals prior IPOs of 32 firms over 2000-2008.

Pearson correlation matrix is shown in Table 3. Duality role of $\mathrm{BoC}$ has significant and negative correlation with DAC $(p<0.01)$, firm size correlates positively with DCA $(p<0,05)$ and the presence of independent $\mathrm{BoC}$ has positive correlation with DCA $(p<0,10)$. Firm size is positively correlated with size of $\mathrm{BoC}(p<0.01)$ indicating the larger the firm size the larger the number of BoC. Firm size, leverage, and profitability are found to have no significant correlation with the level of discretionnary accruals. Other findings show that larger firms tend to have larger leverage. In addition, larger firms tend to have larger number of size of Board of Commissioner.

Table 4 shows the results of hypotheses testing. The results reported in Table 4 confirm the 
finding shown in Table 3 concerning the correlation between duality role (DUAL) and the level of discretionary accruals (DAC). The coefficient of duality role of $\mathrm{BoC}$ is positive and significant $(p<0.01)$. Size of BoC affects DAC positively at traditional level, it is in contrast to the prediction $(p<0.10)$. Profitability positively affects earnings management $(p<0.05)$. Other variables, i.e., the presence of independent $\mathrm{BoC}$, firm size, and leverage do not have significant effect on earnings management in IPOs.

This study shows that when IPO firms have BoC who is also being the director, or termed to have dual role, they have has to perform monitoring the firm as well as being the agent. It appears that $\mathrm{BoC}$ are unable to performed dual role, i.e., as monitoring and governing. This leads to the higher earnings management. The reported result is consistent with Saleh et al. (2005). It indicates that $\mathrm{BoC}$ having more than one role tends to have lower level of monitoring. The dual function will split the concentration and their focus on responsibility as well handling problems making the control and monitoring function on management less optimal so that earnings management occurs.

A deeper examination shows that some of BoC of IPO firms have similar role in more than two other firms. This condition has lessened the time allocated to monitor firm's management.

The findings reported here is robust in terms of the significant relationship between duality role of $\mathrm{BoC}$ and earnings management under various regression models. This means that the finding is not affected by other independent variables.

Table 3. Correlation Matrix of Variables

\begin{tabular}{lllllll}
\hline Variable & DCA & DUAL & SC & IND & FS & LEV \\
\hline DUAL & $0.3839^{\mathbf{a}}$ & & & & & \\
SC & $0.2310^{\mathbf{b}}$ & 0.0762 & & & & \\
IND & $0.1873^{\mathbf{c}}$ & 0.1569 & $0.3535^{\mathbf{a}}$ & & & \\
FS & 0.0506 & 0.0060 & $0.5418^{\mathbf{a}}$ & $0.4151^{\mathbf{a}}$ & & \\
LEV & -0.0274 & 0.0538 & 0.1131 & $0.1746^{\mathbf{c}}$ & $0.3827^{\mathbf{a}}$ & \\
PRO & 0.1109 & $-0.1932^{\mathbf{b}}$ & 0.0441 & -0.1509 & 0.1287 & 0.0623 \\
\hline
\end{tabular}

a, b, c indicate significant at $1 \%, 5 \%$, and $10 \%$, respectively.

Notes:

$\mathrm{DCA}=$ discretionary current accruals, DUAL = duality role of BoC, $\mathrm{SC}=$ Size of BoC, IND = Independent BoC, $\mathrm{FS}=$ firm size, LEV = leverage, $\mathrm{PRO}=$ Profitability.

Table 4. Results of Regression Analyses

\begin{tabular}{|c|c|c|c|c|c|c|}
\hline Description & Prediction & $\begin{array}{c}\text { Coefficient } \\
\text { (t-value) }\end{array}$ & $\begin{array}{l}\text { Coefficient } \\
\text { (t-value) }\end{array}$ & $\begin{array}{c}\text { Coefficient } \\
\text { (t-value) }\end{array}$ & $\begin{array}{l}\text { Coefficient } \\
\text { (t-value) }\end{array}$ & $\begin{array}{c}\text { Coefficient } \\
\text { (t-value) }\end{array}$ \\
\hline & & Model 1 & Model 2 & Model 3 & Model 4 & Model 5 \\
\hline DUAL & + & $\begin{array}{c}1.6324 \\
(3.1733)^{\mathrm{a}}\end{array}$ & $\begin{array}{c}1.6477 \\
(3.2321)^{\mathrm{a}}\end{array}$ & $\begin{array}{c}1.4816 \\
(2.8653)^{\mathrm{a}}\end{array}$ & $\begin{array}{c}1.4689 \\
(2.8680)^{a}\end{array}$ & $\begin{array}{c}1.5039 \\
(2.9572)^{\mathrm{a}}\end{array}$ \\
\hline $\mathrm{SC}$ & - & $\begin{array}{c}0.2903 \\
(1.5187)^{\mathbf{c}}\end{array}$ & $\begin{array}{c}0.2069 \\
(1.2336)\end{array}$ & $\begin{array}{c}0.2976 \\
(1.5274) \mathrm{c}\end{array}$ & $\begin{array}{c}0.3077 \\
(1.6052) \mathbf{c}\end{array}$ & $\begin{array}{c}0.2366 \\
(1.4000) \mathbf{c}\end{array}$ \\
\hline IND & - & $\begin{array}{c}0.5539 \\
(1.0875)\end{array}$ & $\begin{array}{c}0.3681 \\
(0.7667)\end{array}$ & $\begin{array}{c}0.3732 \\
(0.7337)\end{array}$ & $\begin{array}{c}0.3671 \\
(0.7277)\end{array}$ & $\begin{array}{c}0.2494 \\
(0.5189)\end{array}$ \\
\hline FS & - & $\begin{array}{c}-0.3184 \\
(-0.8599)\end{array}$ & - & $\begin{array}{c}-0.2193 \\
(-0.5878)\end{array}$ & $\begin{array}{c}-0.2739 \\
(-0.7949)\end{array}$ & - \\
\hline $\mathrm{LEV}$ & + & $\begin{array}{l}-0.5068 \\
(-0.4614)\end{array}$ & - & $\begin{array}{c}-0.4473 \\
(-0.3996)\end{array}$ & - & - \\
\hline PRO & + & $\begin{array}{c}2.7089 \\
(1.7645)^{\mathbf{b}}\end{array}$ & $\begin{array}{c}2.3939 \\
(1.5927)^{\mathbf{c}}\end{array}$ & - & - & - \\
\hline Adj.R ${ }^{2}$ & & 0.1628 & 0.1717 & 0.1301 & 0.1434 & 0.1489 \\
\hline $\begin{array}{l}\text { F-value } \\
(p=\text { value })\end{array}$ & & $\begin{array}{c}2.9126 \\
(0.0157)\end{array}$ & $\begin{array}{c}4.0579 \\
(0.0059)\end{array}$ & $\begin{array}{c}2.7642 \\
(0.0270)\end{array}$ & $\begin{array}{c}2.7642 \\
(0.0270)\end{array}$ & $\begin{array}{c}4.4430 \\
(0.0072)\end{array}$ \\
\hline Durbin-Watson & & 2.335 & 2.265 & 2.192 & 2.159 & 2.141 \\
\hline
\end{tabular}

a, b, c indicate significant at 1\%, 5\%, and $10 \%$, respectively.

Notes:

$\mathrm{DCA}=$ discretionary current accruals, $\mathrm{DUAL}=$ duality role of $\mathrm{BoC}, \mathrm{SC}=$ Size of BoC, IND $=$ Independent BoC, FS = firm size, LEV = leverage, $\mathrm{PRO}=$ Profitability. Models 2 to 5 are presented for comparison purpose. 
The study shows that size of $\mathrm{BoC}$ has positive coefficient on DAC. This means that the larger the size of $\mathrm{BoC}$ the higher is the level of earnings management. This contradicts with the prior the expectation that the more the BOC's members lower the level of earnings management as the monitoring power increases (Dalton et al., 1999; Bradbury et al., 2006). This finding should be treated with caution. It seems that the presence of $\mathrm{BoC}$ does not effective in preventing management for conducting any action whichaffects earnings management. The question raised in relation to the finding reported here is that there is no guarantee that larger size of $\mathrm{BoC}$ could be effective in monitoring the management of firm.

Profitability is positively related to earnings management. This finding supports the previous reports that IPO firms tend to make income which increases discretionary accruals (Friedland 1993; Teoh et al. 1998). This implies that reported earnings can give sightsthat the issuing firms are profitable. Out of 60 sample firms, only 12 firms reported loss in their financial reports prior to IPO. Godfrey and Koh (2003) conversely reported negative coefficient of profitability in Australian IPOs.

This study does not find that the presence of independent $\mathrm{BoC}$ reduces the level of earnings management. Independent $\mathrm{BoC}$ seems to have low or even no control of management given the fact that her presence is voluntary. Some may pessimistically view that the function of independent $\mathrm{BoC}$ of firms making IPO is just to meet the suggestion imposed by the capital market governing body. Whether its existence is just a part of obedience or to meet a good governance is still questionable.

Unlike Aharony et al. (1993), who found that smaller firms tend to make income increasing discretionary accruals, this study does not find any evidence that firm size is related to earnings management. Dividing the sample firm into small and large firms shows that the average DCA of small firms is 0.5472 and for larger firms is -0.1645 and the difference is not statistically significance $(\mathrm{t}=-0.8716 ; \mathrm{p}=0.1953)$. Thus, it appears that accounting earnings of IPO firms do not affect management intention to manage reported earnings through discretionary accruals.

The study finds that leverage level is not associated with earnings management. This is in contrast to DeFond and Jiambalvo (1994) who document that larger firms tend to make income increasing discretionary accruals as an effort to improve earnings performance. Godfrey and Koh (2003) find positive and significant effect of leverage on discretionary accruals in Australian IPOs.

\section{CONCLUSIONS}

Duality role of $\mathrm{BoC}$ is found to be positively related to earnings management in Indonesian IPOs. This indicates that when IPO firms have $\mathrm{BoC}$ who is not only being a commissioner but also being a director, the incidence of earnings management is getting intense as a result of weakening monitoring role. The number of $\mathrm{BoC}$ is also positively related to earnings management along with firms' profitability. The presence of independent $\mathrm{BoC}$, firm size, and leverage do not have effect on earnings management level.

Some cautions merit attention. First, this study uses cross-sectional base estimation of discretionary accruals used by firms in the same sub-sector. It may not be a good measure given existing firms may have better financial structure and lower intension to manage earnings. Studies estimating earnings management level have used various measures (Beneish, 1998) and as noted by Ronen and Yaari (2008), there are various measures of discretionary accruals that have been employed in earnings management studies, making it possible to obtain different results when studying earnings management.

The study does not explicitly examine the role of $\mathrm{BoC}$ in reducing earnings management. So, this study is unable to differentiate whether earnings management is caused by the nature or the evaporating role of $\mathrm{BoC}$.

Some suggestions are put forward. First, future study may compare the level of earnings management between sectors by considering two state of the market that is during bull and bear IPO market to seek evidence whether earnings management is related to the IPO cycle. Using other estimation in measuring discretionary accruals is also recommended by adjusting the number of IPO firms, either using market or sector base, not sub-sector as used in this study, or by using IPO base year. Future study may also examine whether there is difference in terms of the magnitude of discretionary accruals between before and after IPO. Roosenboom et al. (2003) show strong evidence on profit decrease after IPO in the Netherlands and Teoh et al. (1998) in the US IPOs. Comparison between before and after IPO may strengthen the findings of previous studies of common earnings management practice in IPO setting. The Indonesian capital market governing body shall consider banning firm with duality role so BoC's monitoring role could be more effective leading to lowering the possibility of earnings management in IPO firms. 


\section{Acknowledgement}

We thank very much to anonymous participants at the International Seminar of University Industry Business Linkage (UIBL) held by University of Mercubuana for comments and constructive suggestions.

\section{REFERENCES}

Aharony, J., C.J. Lin, \& M.P. Loeb (1993), "Initial public offerings, accounting choices, and earnings management", Contemporary Accounting Research 10 (1): 61-81.

Beasley, M.S. (1996), "An empirical analysis of the relation between the board of director composition and financial statement fraud", The Accounting Review, 71 (4): 443-465.

Beiner, S., W. Drobetz, F. Schmid, \& H. Zimmermann (2004), "Is board size an independent corporate governance mechanism?", International Review for Social Science 57 (3): 327356.

Beneish, M.D. (1998), "Discussion of: Are accruals during initial public offerings opportunistic?", Review of Accounting Studies 3: 209-211.

Bradbury, M.E., Y.T. Mak, \& S.M. Tan (2006), "Board characteristics, audit committee characteristics and abnormal accruals", Pacific Accounting Review 18 (2): 47-68.

Cornett, M.M., A.J. Marcus, A. Saunders, \& H. Tehranian (2006), Earnings management, corporate governance, and true financial performance. http://papers.ssrn.com.

Dalton, D.R., C.M. Daily, J.L. Johnson, \& A.E. Ellstrand (1999), "Number of directors and financial performance: A meta analysis", Academy of Management Journal 42 (6): 674-686

De Fond, M.L. \& J. Jiambalvo (1994), "Debt covenant violation and manipulation of accruals", Journal of Accounting and Economics 17: 145-176.

Dechow, P.M., R.G. Sloan, \& A.P. Sweeney (1995), "Detecting earnings management", Accounting Review 70: 193-225.

Fama, E.F. \& Jensen, M.C. (1983), "Separation of ownership and control", Journal of Law and Economics 26: 1-32.

Friedlan, M.L. (1994), "Accounting choices of issuers of initial public offerings", Contemporary Accounting Research 11(1): 1-31.

Godfrey, J.M., \& P.S. Koh (2003), "The Association between Firms' Public Finance Issues and Earnings Management”, Accounting Research Journal 16 (2): 102-116.

Guest, M.P. (2008), "The determinants of board size and composition: Evidence from the UK", Journal of Corporate Finance 14: 51-72.
Gumanti, T.A. (2001), Earnings Management dalam Penawaran Saham Perdana di Bursa Efek Jakarta (Earnings management in Initial Public Offerings in Jakarta Stock Exchange), Jurnal Riset Akuntansi Indonesia 4 (2): 165-183.

Guna, W.I. \& Herawati, A. (2010), "Pengaruh mekanisme good corporate governance, independensi auditor, kualitas audit dan faktor lainnya terhadap manajemen laba (The effect of good corporate governance, independent auditor, audit quality and other factors on earnings management)", Jurnal Bisnis dan Akuntansi 12 (1): 53-68.

Hastoro, H.A. \& Yuliana, A. "Manajemen laba di sekitar penawaran saham perdana (initial public offering=IPO) pada perusahaan manufaktur di Bursa Efek Indonesia (Earnings management in initial public offerings of manufacturing firms in Indonesia Stock Exchange)", Jurnal Ekonomi dan Bisnis 1 (1): $67-80$.

Healy P.M. \& Wahlen, J.M. (1999), "A review of the earnings management literature and its implications for standard setting", Accounting Horizon 13 (4): 365-383.

Jensen, M.C. \& Meckling, W.H. (1976), "Theory of the firm: Managerial behavior, agency costs and ownership structure", Journal of Financial Economics 3, 305-360.

Jones, J.J. (1991), "Earnings management during import relief investigations". Journal of Accounting Research 29 (2): 193-228.

Joni (2008), "Hubungan manajemen laba setelah ipo dan return saham dengan kecerdasan investor sebagai variabel pemoderasi (The relationship of earnings management after IPO and stock returns with investor intelegence as moderating variable)", Jurnal Ilmiah Akuntansi, 7 (1): 1-17.

Kaznik, R. (1999), "On association between voluntary disclosure and earnings management", Journal of Accounting Research 37: 57-81.

Klein, A. (2002), "Audit committee, board of director characteristics, and earnings management", Journal of Accounting and Economics 33 (3): 375-400.

Magnan, M. \& D. Cormier (1997), "The impact of forward-looking financial data in IPOs on the quality of financial reporting", Journal of Financial Statement Analysis 3 (2): 6-17.

Neill, J.D., S.G. Pourciau, \& T.F. Schaefer (1995), "Accounting method choice and IPO valuation", Accounting Horizons 9(3): 68-80.

Pierce, J.A \& S.A. Zahra (1992), "Board composition from a strategic contingency perspective", Journal of Management Studies 28:411-438. 
Rahman, R.A \& F.H.M. Ali (2006), "Board, audit committee, culture and earnings management: Malaysian evidence", Managerial Auditing Journal 21 (7): 783-804.

Rechner, P.L. \& Dalton, D.R. (1991), “CEO duality and organisational performance: A longitudinal analysis", Strategic Management Journal, 12: 155-160.

Ronen, J. and Yaari, V. (2008), Earnings anagement: Emerging Insights in Theory, Practice, and Research, Springer, New York.

Roosenboom, P., van der Goot, T. \& G. Mertens (2003), "Earnings management and initial public offerings: Evidence from the Netherlands", The International Journal of Accounting 38: 243-266.

Saiful (2004), "Hubungan manajemen laba (earnings management) dengan kinerja operasi dan return saham di sekitar IPO (The relationship of earnings management with operating performance and stock returns surrounding IPO)”, Jurnal Riset Akuntansi Indonesia 7 (3): 316-332.
Saleh, N.M., Iskandar, T.M. \& Rahmat, M.M. (2005), "Earnings management and boards characterristics: Evidence from Malaysia", Jurnal Pengurusan 24: 77-103.

Teoh, S.H., Wong T.J. \& Rao, G.R. (1998), "Are accruals during initial public offerings opportunistic?", Review of Accounting Studies 3: 175-208.

Tykova, T. (2006), IPOs and Earnings Management in Germany, In Gregoriou, Greg N. Initial Public Offering: An International Perspective. Burlington: Butterworth-Heinemann, pp. 281296.

Yermack, D. (1996), "Higher market valuation of a company with a small board of directors", Journal of Financial Economics 40 (2): 185211.

Zahra, S.A. \& J.A., Pearce, II (1989), "Board of directors and corporate financial performance: A review and integrative model", Journal of Management 15: 291-334. 